\title{
Understanding private forest owners' conceptualisation of forest management: Evidence from a survey in seven European countries
}

Authors: Diana Feliciano ${ }^{1}$, Laura Bouriaud ${ }^{2}$, Elodie Brahic ${ }^{3}$, Philippe Deuffic ${ }^{3}$, Zuzana Dobsinska ${ }^{4}$, Vilem Jarsky ${ }^{5}$, Anna Lawrence ${ }^{6}$, Erlend Nybakk ${ }^{7}$, Sonia Quiroga ${ }^{8}$, Cristina Suarez ${ }^{8}$, Andrej Ficko ${ }^{9}$

${ }^{1}$ Corresponding author: Institute of Biological and Environmental Sciences, School of Biological Sciences, University of Aberdeen, 23 St Machar Drive, Room G43, Aberdeen AB24 3UU, Scotland, United Kingdom

E-mail: diana.feliciano@abdn.ac.uk Tel: +44 (0)1224 273810

${ }^{2}$ Universitatea Stefan cel Mare, Romania

${ }^{3}$ Irstea UR ETBX (National Research Institute of Science and Technology for Environment and Agriculture)

${ }^{4}$ University of Technology in Zvolen, Slovakia

${ }^{5}$ Czech University of Life Sciences Prague, Czech Republic

${ }^{6}$ University of Highlands and Islands, Scotland, United Kingdom

${ }^{7}$ Høyskolen Kristiania, Norway

${ }^{8}$ University of Alcala, Spain

${ }^{9}$ University of Ljubljana, Biotechnical Faculty, Slovenia

\begin{abstract}
:
Private forest owners' involvement in forest management has been frequently examined through the attitudes, values, beliefs, objectives and motivations associated with owning and managing forestland. Owners' views on forest management do not always align with those of policymakers who believe forest owners do not actively manage their forests. However, empirical studies on forest owners' conceptualisations of forest management are scarce. To determine how private forest owners in Europe conceptualise forest management, a survey $(n=1,140)$ was undertaken in seven European countries (Portugal, France, the United Kingdom, the Czech Republic, Slovenia, Slovakia and Romania). The owners were asked to indicate their level of agreement with 19 pretested statements defining forest management on a five-point Likert scale. Classification and regression trees were used to explain the major factors that influenced owners' conceptualisations. Owners primarily conceptualised forest management as preserving forests for future generations and considered "a good business opportunity", "an opportunity to earn additional money" or a "source of subsidies" less important. Their understanding of forest management as a mixture of
\end{abstract}


forest maintenance, ecosystem stewardship and economic activity does not match with alleged policy makers' views. Property size, age and Eastern/Western countries were the most relevant predictors of definitions of forest management. Small-scale forest owners from Western Europe considered ecosystem orientation more important, while owners from Eastern Europe considered economic aspects and forest maintenance more important. These differences might be associated with the socio-political system dynamics in Europe in the $20^{\text {th }}$ century and changing values in postmodern society. Policymakers must be aware of the different forest management paradigms among forest owners in Eastern-Central and Western Europe when designing European forest policies.

Keywords: social representations, natural resource management, private forest owners, multifunctionality.

\section{Introduction}

Forests cover approximately $33 \%$ of Europe's total land area ${ }^{1}$ (Forest Europe, 2015). More than half of European forests are privately owned, mostly by individuals and families with small and fragmented forest properties (Schmithüsen and Hirsch, 2010). Europe's rural landscapes and rural society have changed remarkably in recent decades (Lieskovský et al., 2015; Soares da Silva et al., 2016; van Vliet et al., 2015). The number of farms has steadily declined, and the vast majority of farmers have replaced farming activities with other activities (European Commission [EC], 2013), which are usually more profitable. While small-scale forest owners used to be farmers and representatives of rural society, current forest owners have become urbanised and less attached to their forestlands (e.g., Kvarda, 2004; Hogl et al. 2005; Karppinen, 2012).

With the political changes in Eastern Europe during the 1990s, many public forests have been returned to private ownership, which has contributed to an $18 \%$ increase in private forest area in Europe (Forest Europe, 2015). Policy reforms and economic liberalisation in Southeast Europe established new actors and institutional arrangements (Weiland, 2010). In some Western European countries, forests have also been transferred from public to private ownership as a result of the adoption of more neoliberal policies (Hodge and Adams, 2013, 2014), and land grabbing has also become a European problem (van der Ploeg et al., 2015). Therefore, land acquisition is a latent process that shapes the future of European rural areas.

However, independent of the particular process behind forest ownership (e.g., purchases, inheritance, and restitution) and the ownership type (e.g., individuals or legal entities), private forest owners play a determinant role in sustaining forest ecosystems, maintaining traditional silvicultural practices, supplying wood and other goods and services to the market and, more generally, enhancing rural development. These activities are the basis for sustainable forest management defined by the Ministerial Conference on the Protection of Forests in Europe, held in Helsinki in 1993, as "using forests and forest land in a way, and at a rate, that maintains their biodiversity, productivity, regeneration capacity, vitality and their potential to fulfil, now and in the future, relevant ecological, economic and social functions, at local, national, and global levels, and that does not cause damage to other ecosystems." This definition was introduced almost in the same terms in the national legislation of all of the EU 27 Member States. In 2006, the European Council also adopted an EU Forest Action Plan in order to provide a coherent framework for implementing forest-related measures and to serve as an instrument of co-ordination between the EU and the forest policies of Member States. More recently, this definition has been adopted by the European Forest Strategy (EU, 2013).

\footnotetext{
${ }^{1}$ Excludes the Russian Federation.
} 
To support sustainable forest management and rural development, most European countries have introduced financial instruments, mainly within EU Rural Development Programmes 2007-2013 (Rametsteiner, n.d.). However, the uptake of the financial subsidies that are embedded in these programmes will likely be correlated with the forest owners' utilitarian values. But Madsen (2003) found that Danish farmers who apply for voluntary subsidy schemes share a wide range of practices and values concerning afforestation. Ficko and Boncina (2013) emphasised that the economically rational behaviour of materialist forest owners in Slovenia is not necessarily based on a utility maximisation strategy but also on the historical and social background. Targeting forest owners who have diverse management objectives, changing lifestyles and, in some cases a weak sense of place and attachment to forests represents a significant challenge for policymakers who are charged with implementing forest policies (e.g., Lawrence and Dandy, 2014). To address this challenge, a wider range of policy instruments are required in order to meet the increasing demands for public benefits and wood mobilisation from private forests (Urquhart et al., 2012).

Governments across Europe prioritise the involvement of private forest owners in active management of their forest sector agenda (Forests Europe, 2015). While the predominant narrative from policy-makers is a low level of interest and management activity, woodland owners claim to actively manage their woodlands, on their own terms (e.g., Ficko and Boncina, 2015a; Independent Panel on Forestry, 2012; Lawrence and Dandy, 2014). In France, a simplified forest management plan has been implemented as a tool to support private forest owners to manage their forests. However, it has been reported that only $6 \%$ of forest owners, representing $42 \%$ of the forest cover, have an official document specifically dedicated to forest management, and $50 \%$ of forest owners manage their forest by themselves or with the help of a family member or a forest advisor (Agreste, 2013). This suggests that state authorities view the management plan as a control rather than as a support tool for forest owners (Agreste, 2013). Bouriaud et al. (2013) mentioned that in several Eastern and Central European countries, forest management is subject to compulsory forest planning, carried out under the supervision of a State agency with little or no participation from forest owners. State-led planning is therefore viewed as the main instrument to ensure the sustainable management of forest resources, implementing and transposing the central legal norms at the local level (Bouriaud et al., 2013). However, private forest owners may consider such forest management to be a "carrot and stick" approach or a symbol of overregulation (Brukas and Sallnäs, 2012; Quartuch and Beckley, 2014; Serbruyns and Luyssaert, 2006). In Finland, Hokajärvi et al. (2009) noticed that while planning continued to focus on traditional wood production, the interests of the forest owners rarely aligned seamlessly with the policy targets of timber procurement. In Sweden, professional foresters have been shown to be more favourably inclined towards management for timber compared with owners. As foresters manage the woods on behalf of the owners (Kindstrand et al., 2008), they presumably have a strong influence. Summarising the wider literature from the UK, Lawrence and Dandy (2014) concluded that the "language used by researchers reflects an implicit standard: management is seen as 'suboptimal', and there is a need for owners to 'properly manage'" their forests.

It seems there is a mismatch between the "official" message on what forest management should be, and how forest owners interpret it in their daily forestry routines. Forest owner interpretation of forest management embodies their values, beliefs and practices, and it is one of the most visible signs of owner involvement in forestry. Furthermore, private landowners respond to a wide range of policies, among which forestry policy often plays a minor role (Lawrence and Dandy, 2014). In many cases, the extension officers of local forest management associations, local wood purchasers and family members are the most significant sources of normative pressures that affect the decisionmaking processes of forest owners (Gootee et al., 2010; Karppinen and Berghäll, 2015). In contrast, private forest owners do not always follow the advice provided by the forest management services because the former's views of forest management do not always coincide with those of the latter (Davis and Fly, 2004). Gootee et al. (2010) reported that many natural resource management 
professionals failed to explain the rationale behind new concepts or regulations before requiring the non-industrial private forest owners to implement them and as a result, the owners were reluctant to accept or adopt much of the information provided.

The contrasts between policy makers' and forest owners' perceptions of forest management have contributed to an increasing lack of trust towards foresters and state mechanisms for forest management (Davis and Fly, 2010; Kittredge, 2004). To look beyond forest owners' management objectives, this study adopted the social representations theory of Moscovici (2008). This theory has previously been used by Ficko and Boncina (2015a) to empirically explore how private forest owners conceptualise forest management. Several European social psychology and rural sociology studies (e.g., Halfacree, 1995; Smith and Phillips, 2001; Soares da Silva et al., 2016) have also used this theory. Specifically, the theory defines social representations as a configuration of attitudes, beliefs, knowledge, and emotions that are built around a socially relevant object and shared by social groups. Social representations are forms of social knowledge, such as value systems, beliefs, opinions, semantic repertoires, and theories of common sense that result from a process of reconstructing reality into a symbolic system that is elaborated in relation to socially relevant objects through communication exchanges between people in groups and communities (Doise, 1989). Social representations are thus a type of map of the semantic field relative to an object (e.g., "forest management"). Within this common field of reference, different social representations of the same object could be developed by distinct social groups according to the relevance the object has for them, i.e., the symbolic distance between the object and the social group results in different ways of thinking about it (Cavazza and Rubichi, 2014). For example, in the French context, the notion of "forest management" is strongly linked to policy control (Barthod et al., 2001).

Despite the diverse meanings associated with social representation models, the core elements are consistent and relatively stable (Abric, 2001). However, these commonalities do not imply that social representations are invariant across the countries. The representation of a social group should be interpreted within the framework of existing knowledge structures and should always consider a more holistic approach that integrates various attitudinal components (Buijs, 2009). For instance, the attributes of the individuals within the group, such as a person's identity, have been considered important predictors of behaviour (Burton, 2004). Follo et al. (2016), for example, demonstrated that gender matters in forest ownership, management, operations, and the understandings of these three aspects. Many studies (e.g., Stanislovaitis et al., 2015) found that pursuing income from forest management is strongly linked to the size of forest holdings and that only larger private forest owners regard income as a top priority. Matilainen and Lähdesmäki (2014) showed that timber production values might be more emphasised in countries with high proportion of private forests and free public access to nature. Bouriaud et al. (2013) found that, in Eastern countries, forest owners' perceptions of management differ from those in Western countries due to differences in the political systems and the consequences of the forest privatisation process in the Eastern countries.

Therefore, this study follows a hypothesis-testing approach to determine whether social, environmental and economic factors influence conceptualisations of forest management. It follows McGuire et al. (2015), who considered that farmers' identities can be used to predict their reactions to a particular landscape-level policy. This study aims to provide new insights into the representations of sustainable forest management to better understand whether current forest and rural development policy instruments meet the rationale of forest owners. Policymakers' assumptions that forest owners do not actively manage their forests may arise from the lack of empirical studies on how forest management is understood and how it correlates with forest owners' behaviours. In addition, policymakers, rural economists and environmental psychologists must pay equal attention to how forests and their services are perceived by the various types of forest users (Elands and Wiersum, 2001) whose values are more urban than rural based. In Europe, 
most studies on the role of forests have focussed mostly on public perceptions (e.g., EC, 2016; Rametsteiner and Kraxner, 2003; Rametsteiner et al., 2009). This is the first study in Europe where private forest owners' understanding of forest management is compared across different countries.

The three main research questions addressed are as follows: (1) Do European private forest owners share a common understanding of forest management as a mixture of economic, ecosystem and social components? (2) Do European private forest owners have a different level of economic expectations, ranging from "no benefit" to "maximisation of profit", depending on their sociodemographic profiles? (3) Do forest owners from Eastern European, post-socialist countries have different perceptions of forest management than their Western European counterparts?

\section{Methods}

\subsection{Sampling and data collection}

Data were collected in Portugal, France, the United Kingdom, Slovenia, the Czech Republic, Slovakia and Romania via telephone, online, mail and face-to-face surveys. Except for the survey in Slovenia, which was completed in 2013, all the surveys were conducted as part of the COST Action FP1201 Forest Land Ownership Changes in Europe: Significance for Management and Policy (FACESMAP) in 2014 and 2015. The participant countries were selected in order to ensure diversity in terms of political (e.g. Post-socialist, Western governments), social (e.g. employment in forestry, forest ownership types), economic (e.g. importance of forest in GDP), institutional (e.g. share of private ownership) and geographical (Western, Eastern, Northern, Southern, Central European European) characteristics. Because none of the surveys was financially supported by FACESMAP, different sampling design and data collection methods were used, depending on the resources available to finish the survey within the given timeframe (Table 1).

Random representative sampling was used in Slovenia; convenience sampling was performed in France; snowball sampling was used in Slovakia, the Czech Republic, and Romania; and unrepresentative sampling among members of forest owner associations was performed in North and Central Portugal. In the United Kingdom, data collection started with convenience sampling (through links with one small woodland owners' association), but this progressed to snowball sampling through a range of social media to eventually reach several hundred owners, all personal owners of their forest as distinct from commercial investment forestry. Convenience sampling only considers members of the population who are conveniently available at the time of the survey. The first available primary data source was used, with the requirement that the sample was as representative as possible. In convenience sampling, no inclusion criteria were identified prior to the selection of forest owners, and all subjects were invited to participate. Some advantages of using convenience sampling include the simplicity of sampling and the ease of research, the short duration of the survey and the cost-effectiveness of data collection. Snowball sampling is a non-probability sampling technique in which existing study subjects recruit future subjects from among their contacts. This technique is often used when the population under investigation is difficult to approach either due to a low number of potential participants or the sensitivity of the topic. In Slovakia, the Czech Republic, and Romania, snowball sampling helped overcome the problem of nonreachable forest owners and the time available to collect the data. In Portugal and the United Kingdom, accessing a comprehensive list of land owners was not possible due to the lack of a forest cadastre. In these two countries, the sampling was thus conducted with the support of forest owner associations, which reached forest owners who were recorded in their membership lists. Forest owners with no affiliation with a forest owner association were not sampled. The data collection methods were not harmonised; however, this does not necessarily represent a disadvantage. Kanuk and Berenson (1975), Martin (1994) and Dillman (2007) have noted a negative attitude towards 
survey research industries that can inhibit responsiveness. The involvement of universities (Slovenia, Romania, Slovakia and the Czech Republic), research institutes (France) and forest owner associations (Portugal and the United Kingdom) was likely to have provided more interviewees than those who would have been available if these organisations had not been involved.

Although the samples from Portugal, France, Slovakia, the Czech Republic, Romania and the United Kingdom were not representative and thus not valid for country-wide analyses, there is no reasonable assumption that the samples are biased. Moreover, rather than being a representative opinion survey in Europe, this study attempted to empirically analyse how European private forest owners conceptualise forest management and to draw insights instead of overgeneralising the results at the country level.

\section{[Table 1 here]}

\subsection{Survey design}

The respondents were asked to indicate their level of agreement with the 19 statements about forest management on a standard five-point Likert scale ( $1=$ strongly disagree, $5=$ strongly agree) (Table 2). The 19 statements were taken from the questionnaire used in the national study of Ficko and Boncina (2015a) and were translated into six languages (English, Portuguese, French, Slovak, Czech and Romanian). The statements considered activities such as forest operations, forest recreation, provision of ecosystem services, biodiversity protection and the imitation of natural processes as a part of woodland management (Glynn et al., 2012). The remaining questions (control variables) addressed age, gender, total forest area, the number of forest holdings and education.

\section{[Table 2 here]}

Descriptive statistics of the samples (Table 3) and Spearman rank correlations between the control variables (Table 4) are presented below.

\section{[Table 3 here] [Table 4 here]}

The statements targeted the notion of multifunctionality as a cornerstone of most national forest policies in the EU 27. However, even though forest policies are supposed to steer individual behaviours, forest owners still have the capacity to modify, challenge or ignore the rules, especially with respect to very broad concepts such as forest management, in order to have more room for maneuvering (Cleaver, 2012; de Koning, 2014). To explain the complexity of forest owners' values and their attitudes towards forests and behaviour, a multitude of value-attitude-behaviour hierarchy models (e.g., Karppinen and Berghäll, 2015) and private forest owner typologies (e.g., Baptista and Santos, 2005; Hogl et al., 2005; Ingemarson et al., 2006; Lunnan et al., 2006; Ní Dhubháin et al., 2007; Nybakk and Hansen, 2008; Nybakk et al., 2009; Urquhart et al., 2012; Stanislovaitis et al., 2015) have been developed, especially for Western European countries. The formulation of the 19 statements included in the survey considered the policy rhetoric but also resembled the multitude of owner management objectives that are recognised in private forest owner typologies and assumed an association between the representation of forest management and management behaviour.

The percentage of item non-responses was below $1 \%$. To test for the existence of a specific pattern of missing data, a missing completely at random (MCAR) test was performed. The MCAR test estimated whether a significant relationship existed between the missing data and the values, observed or missing. The null hypothesis for the MCAR test is that the data are missing completely at random. The insignificance of the MCAR test (Chi-Square $=473.623, D F=427, p=0.059$ ) means that 
the null hypothesis cannot be rejected. Therefore, the missing values were imputed with the mean as a replacement value.

\subsection{Descriptive analyses}

Mean values and standard deviations were calculated for 19 statements related to the concept of forest management. The most and least agreed-upon statements in a pooled sample were identified according to the following control variables: gender, education, country and European region (East/West). When appropriate, a two-sided independent sample t-test or ANOVA was used to compare the mean scores for the different forest management statements between the levels of control variables. The relationship between the continuous variables (i.e., the respondent's age and forest property size) and the statements was first visually examined in a scatterplot and then tested using a series of linear regressions between the forest management statements and the control variables. Whenever a linear regression seemed inappropriate, a piece-wise linear regression was performed to assess the non-linear relationships.

\subsection{Multivariate analyses: Classification and Regression Trees (CART)}

The Kaiser-Meyer-Olkin (KMO) measure of sampling adequacy and Bartlett's test of sphericity were performed to determine whether the data were suitable for structure detection. In further exploring the structure, this study built upon the empirical study of Ficko and Boncina (2015a), in which three forest management concepts were identified via structural equation modelling with the same survey instrument. The concepts were labelled as maintenance forest management (MAINT), ecosystemcentred management (EM) and economics-centred management (ECON) (see Table 2). MAINT, EM and ECON were calculated as the means of the respective statements associated with these concepts. To measure the internal consistency of the three created measurement variables, values for Cronbach's alpha and Cronbach's alpha if the item was deleted were computed. The internal consistency of the concepts measured by Cronbach's alpha was acceptable to good, ranging from 0.70 for ECON to 0.80 for MAINT (Table 2).

Classification and Regression Trees (CART) were used to study the multivariate relationships between the major forest management concepts (MAINT, EM and ECON) as dependent variables and as a set of predictors. Relative to the least square multiple regression, the primary advantage of the CART and other tree data-mining algorithms is that CART can address the non-linear relationships between the dependent variable and the predictors. Because the dependent variables were continuous and some of the relationships between these variables and the predictors were non-linear, interactive classification and regression trees (C\&RT) were performed using Statistica 8.0 (StatSoft Inc., 2014). An interactive C\&RT uses a CART algorithm (Breiman et al., 1984) to recursively divide the data into a number of binary splits (nodes), which maximises the model fit until the stopping rule and stopping parameter criteria are reached. Moreover, the C\&RT enabled the interactive combination of automatic tree building, which always seeks maximum improvement in the overall model fit at each split with user-defined tree-building criteria to explore trees with alternative structures.

The stopping rule in building the tree utilised within-node variance. When the sum of the squares accounted for by the proposed split by any predictor could no longer be decreased and the stopping parameters were reached (number of observations in a node less than 25 , maximum number of nodes and levels of 1000 and 25, respectively), the tree-building stopped. A ten-fold cross-validation was used to build the algorithmically best tree, each time using nine samples of the data to estimate the tree structure and the remaining sample to evaluate its validity. The validity of the splits was checked by calculating the two-sample t-test for the equality of means in the nodes. The significance of the t-tests (adjusted for when the equality of variances was not met, as appropriate) is reported in 
the tree graphs. Because automatic tree-building returned easily interpretable results with the best fit and none of the manual adjustments of the three structures seemed reasonable, the algorithmically best regression trees with no adjustments were presented. The discrepancy between the observed data and the data "predicted" by the final tree was evaluated by least squares deviation (LSD), average deviation (AD), and the coefficient of determination, $R^{2}$ (Hill and Lewicki, 2007).

\section{Results}

\subsection{Private forest owners' perceptions of forest management: descriptive analyses} The respondents agreed most with the 97 definition, which defines forest management as "Preserving the forest for future generations" (mean 4.4), followed by q5 ("Taking care of forest health and maintaining the resilience of the forest"; mean 4.2) and q1 ("The application of knowledge to forest management; mean 4.2)". The least agreed-upon statements were those related to the economic aspects of forest management, such as q16, which defines forest management as "A source of subsidies" (2.4); q4, which defines it as "A good business opportunity because it provides good financial revenues" (2.9); and q8, which defines it as "A good opportunity to earn additional money or to improve the family budget" (2.8). These statements were the only ones with which the respondents mostly disagreed (Table 5).

\section{[Table 5 here]}

No differences between men and women, education level and Eastern and Western Europe were found regarding the most agreed-upon definition (Table 6). However, significant differences were found in the level of support for the statements. Men supported q7 ("Preserving the forest for future generations") more than women did (4.5 vs. 4.2 , t-test for equality of means $t(1,116)=-3.533, p<$ 0.000 ), and better-educated forest owners supported this same definition (q7) more than owners with a primary school education did $(F(3)=3.111, p<0.026$, post hoc LSD $p<0.005)$.

\section{[Table 6 here]}

Among the surveyed countries, differences were found in the selection of the most agreed-upon definition. "Preserving the forest for future generations" was the preferred definition in the United Kingdom (mean 4.6), Slovakia (4.6), the Czech Republic (4.3), Portugal (4.6), and France (4.3), while owners in Slovenia and Romania preferred "Preserving large-diameter trees" (4.3) and "Ensuring forest goods for my own consumption" (4.4), respectively.

The direct effect of age and property size on these perceptions was weak and, in some cases, nonlinear. The R-squared in linear regressions ranged from 0.0 for the effect of property size on q8 ("A good opportunity to earn additional money or to improve the family budget"), q18 ("Ensuring that the forest is not neglected and untidy"), and q19 ("Cutting large-diameter trees when they are ready to be cut") to 0.03 for the positive linear relationship between the respondent's age and agreement with q11 ("Imitating natural processes in the forest").

\subsection{Principal concepts of forest management}

The diversity of European private forest owners' understanding of forest management can be described with three principal concepts: maintenance forest management (MAINT), ecosystemcentred management (EM) and economics-centred management (ECON). Forest owners regarded $E M$ as the most important dimension (mean value for EM in a pooled sample was 4.1). Forest and forest property maintenance was considered a slightly less important dimension (3.8), whereas economic aspects were not considered important (2.9). The concepts were significantly correlated, 
particularly EM and MAINT $(r=0.53, p<0.05)$. Significant but weaker correlations were found between MAINT and ECON $(r=0.33, p<0.05)$ and EM and ECON $(r=0.31, p<0.05)$.

The Mann-Whitney $\mathrm{U}$ test showed that, in Eastern European countries, forest owners emphasised forest maintenance and forest economics more than forest owners in Western European countries (Table 7). Here, ecosystem-centred management was considered more important.

\section{[Table 7 here]}

\subsection{Multivariate analyses of private forest owner perceptions of forest management}

The support for the MAINT concept primarily depended on the European region, as support was significantly higher in Eastern Europe (Figure 1). This concept was most favoured by small-scale Eastern European forest owners (Figure 1, node with ID $=6$ ). Conversely, forest maintenance was the least important dimension for Western European forest owners with larger properties (Figure 1, node with ID =5). The interaction of property size with the owner's age and European region had a significant effect on the preference for the MAINT concept. On average, small-scale, older and better-educated Eastern European forest owners considered MAINT to be more important than did the owners of larger properties in the West. Gender did not have a significant effect on the differences in the preferences for the MAINT concept. The prediction accuracy of the regression tree was low. The LSD and average AD were 0.48 and 0.53 , respectively, and the coefficient of determination, $R^{2}$, was 0.06 .

\section{[Figure 1 here]}

Support for the EM concept was significantly higher in Western Europe (Figure 2, node with ID = 2). In addition to region (West/East), forest property size was a particularly strong predictor of EM in Western European countries with a non-linear effect (see nodes with ID = 8-15 on the right side of the tree). In the West, the biggest supporters for the EM concept were forest owners with approximately $3.5-5$ ha of forestland (nodes with ID $=11$ and 12 ). This support decreases in the case of forest owners with forest areas both lower and higher than 3.5-5 ha (nodes with ID = 13 and 8). EM was least supported by older small-scale forest owners in Eastern European countries. The model fit was similar to that in the first model; the LSD, $A D$ and $R^{2}$ values were $0.43,0.48$, and 0.07 , respectively.

\section{[Figure 2 here]}

The best predictor of the economics-centred forest management (ECON) was forest property size. In general, larger-scale forest owners favoured the ECON concept more than small-scale forest owners (Figure 3; nodes with ID = 3 and 11). Education and age had an interactive effect on the ECON concept. Less-educated and younger forest owners were more in favour of the ECON concept. In addition, young and small-scale owners (nodes with ID $=6$ ) were the most supportive of the ECON concept. The $L S D, A D$ and $R^{2}$ values were $0.74,0.69$, and 0.07 , respectively. Table 8 summarises the results of the regression trees.

\section{[Figure 3 here]}

\section{[Table 8 here]}

\section{Discussion}




\subsection{Forest management as a mixture of economic, ecosystem and social dimensions}

The results coincide with the conclusions of many private forest owner typologies (for recent reviews, see Straka (2011) and Dayer et al. (2014)), which show that private forest owners have multiple objectives and that sustainable forest management is fully embraced. "Preserving the forest for future generations" was the highest rated definition overall (Table 5), which confirms owners' sense of intergenerational fairness as a pillar of sustainable forest management (Hahn and Knoke, 2010). This study went a step further than the approach taken by most typology studies because it looked beyond the forest owners' management objectives and used a measurement instrument that had been previously validated through a sequence of structural equation models (Ficko and Boncina, 2015a). This trilateral conceptualisation of forest management is in line with that of Hahn and Knoke (2010), who consider that the definition of sustainable forest management needs to be linked to the dimensions of space and time.

However, since the respondents did not sort the statements by importance but expressed their agreement with each statement individually, our results can only reveal how forest management is conceptualised by private forest owners (R-methodology), not how each individual is positioned in the forest management definition space (Q-methodology). Although primary data on individuals' ranking of statements were not collected, the typical response profile of forest owners can be assessed by separately comparing the main characteristics of individuals with higher and lower scores for the three concepts of forest management (Table 8). In order to simultaneously compare the three concepts (bearing in mind that the responses are not Q-sorts), structural equation modelling (e.g., the Multiple Indicators Multiple Causes (MIMIC) model) should be applied. Using MIMIC, the correlations between all statements can be estimated simultaneously, and the strength of the relationships between the three hypothesised constructs and demographic variables can be assessed.

This study showed that private forest owners recognise the long-term nature of forest management, and also describe forest management as preserving forests for future generations. Stanislovaitis et al. (2015) recorded similar statements from Lithuanian forest owners, namely, "I want to show my grandchildren how to grow a forest the right way"; "Keeping [the forest] for future generations is important"; "We grow the forest for the children"; and "[It is important] to leave these holdings for heirs", "that the next generations take over", and "that my son also manages it well". Owners may value their forests because they engender a shared feeling of ownership and belonging. In addition, forests can provide a sense of connectedness to the natural world and a link between the past, the present and the future (Forest Europe, 2011). This concept is similar to forest stewardship, i.e., "management on behalf of others" (Lertzman, 2009) and the "responsible use (including conservation) of natural resources in a way that takes full and balanced account of the interests of the society, future generations, and other species, as well of private needs, and accepting significant answerability to society" (Worrell and Appleby, 2000; cf. Levin, 2003). Raymond et al. (2015) found that farmers with a holistic understanding of landscape stewardship recognised the interactions, as well as the interdependencies, between ecological and production systems. A review conducted in the UK (Lawrence and Dandy 2014) identified several studies that reported custodianship or guardianship as a value shared by many woodland owners (Church and Ravenscroft, 2008; Leach et al., 2012; Nicholls and Young, 2005; Wibberley, 2002). More efforts are required to analyse the spatial impacts of different forest management conceptualisations on a rural landscape and to predict their influence at a landscape level. Raymond et al. (2015), for example, found that farmers with a holistic understanding of landscape stewardship supported a patchwork of different land uses in order to maintain or enhance landscape diversity. The semantic maps of forest management concepts could be used in participatory landscape planning as a layer of spatial planning.

\subsection{Economic expectations from forests}


Economics-centred forest management (ECON) ranked lowest among forest owners, which casts doubt on the effectiveness of wood mobilisation and forest expansion policies in some European countries. One policy at stake is the European Commission renewable energy policy and the associated 20\% renewable energy consumption target for 2020 (EC, 2009), which is highly dependent on wood mobilisation from private forests and, consequently, on forest owners' attitudes towards forest management.

Private forest owners' non-materialistic attitudes have been found in several studies across Europe (Ní Dhubháin et al., 2007). In the United Kingdom, for example, a review of 42 studies on owners' attitudes and decisions concluded that in many cases, landowners were not primarily motivated by making money from woodlands (Lawrence and Dandy, 2014). Some small-scale forest owners consider forest management financially unrewarding because the income from forests is sporadic and limited in time. Unless forests are managed under a single-tree selection system, small-scale forest owners only make money once or twice in their lifetimes when a clearcutting or commercial thinning occurs. Compared with farming, forest management is a long-term activity that requires skills and specific equipment that forest owners may no longer possess.

It should be noted that respondents had to indicate their agreement with pre-defined statements that targeted three concepts associated with forest management. Therefore, it cannot be concluded that the forest's economic value was not important to forest owners. Our findings only suggest that making money is not their primary objective. Although many forest owners believe that forestry is financially unrewarding and not worth the investment, this belief does not imply that they would not plant trees or buy forestland if wood prices were better and/or payments for ecosystem services were implemented. Compared with ten years ago, more small woodland owners in the United Kingdom are currently harvesting their forests because of an increase in firewood prices (personal communication, 08/06/2016). The elasticity between the prices of fossil fuels and prices of woodfuel (Härtl and Knoke, 2014) is likely to influence private forest owners' behaviours.

Many studies showed that pursuing income through forest management is strongly linked to the size of forest holdings, and only large-scale private forest owners regard income as a top priority (e.g., Stanislovaitis et al., 2015). When compared with that of cropland, the lower annual revenue of forests might lead forest owners to think that a large forest area is required to achieve steady income. While generally true in terms of economies of scale, an optimal tree species mixture (e.g., Roessiger et al., 2016) or an optimal portfolio of agroforest land uses (Raes et al., 2016) could increase harvest frequency and, consequently, the net revenue. Nybakk et al. (2009) found that forest size moderates the effect between forest owners' innovation and economic performance, suggesting that large-scale forest owners benefit more from the innovative use of forest land for economic purposes. In this study, the "size of the property" was found to be important when age and education were considered. This was also found by one study in England (Render, 2004). In addition, middle-aged forest owners with low levels of education were found to be more supportive of the ECON concept, perhaps representing the owners who pursue mostly economic goals and search for innovative business models.

It is not easy to synchronise payment schemes with the increasingly fast pace of changes in the agroforestry sector, particularly forest owners' negative attitudes towards subsidies (Thomas et al., 2015). European governments have utilised a variety of financial instruments to support forest management, but their uptake has been limited so far. The EU framework for Rural Development Programmes (RDP) is the main provider of subsidies and incentives to increase the social and ecological resilience of European forests (Forest Europe, 2011). In 2013, a new European Forest Strategy was adopted to respond to the increasing demands on forests and to the substantial societal and political changes that have occurred in the forest sector in recent years. This strategy is based on a broader approach to forest management by bringing together numerous aspects of 
various complementary policy areas (e.g., EU Biodiversity Strategy 2020, EU Bio-economy Strategy) that cover rural development, enterprise, environment, bioenergy, climate change, research and development. This approach aligns well with the United Nations (UN) Sustainable Development Goals and, more specifically, Goal 15- Sustainably manage forests, combat desertification, halt and reverse land degradation, halt biodiversity loss. These overarching policies appeal for national forest policies to orientate themselves towards rural development and sustainability objectives.

The lower importance given to forest management as "a good business opportunity", "an opportunity to earn additional money" or a "source of subsidies" is also supported by Church and Ravenscroft (2008). These authors found that over $50 \%$ of the landowners in south-east England, who were not receiving management grants, felt that these incentives were irrelevant, and over $30 \%$ of the landowners who received such grants felt that they did not affect their decisions. Barriers to the application of forest subsidies, such as bureaucracy and administrative demands, the reliability of policy and incentive schemes in general, the loss of control over the property, and inflexible and restrictive land management regimes, might be difficult to overcome, especially for small-scale forest owners who participated in the current study. Some studies from specific localities in England and Wales, reviewed in Lawrence and Dandy 2014 (Betts and Ellis, 2000; Ward and Manley, 2002; Wavehill Consulting, 2009), showed that some forest owners are unaware of subsidies, as advisory systems are not disseminating information as they should. In Portugal, the respondents, who are also members of forest owner associations, scored low on defining forest management as "a source of subsidies", although one of the primary objectives of Portuguese forest owner associations is to provide information and advice about subsidy availability and application. However, the effectiveness of advisory services in sharing information with forest owners can have some perverse effects. In the United Kingdom, information about subsidies has mainly been channelled to the forest owners via advisory services, which has made owners make decisions based on grants rather than on the wider range of possible objectives (personal communication, 08/06/2016). In Finland, the advisory services that heavily marketed subsidies in the past were found to have encouraged owners not to take care of young forest stands in order to easily obtain subsidies to improve the conditions of their stands (personal communication, 08/06/2016). These two examples elucidate how subsidies might not always contribute to the objectives of national, European or global policies. Another reason that "forest management as a source of subsidies" was considered the least important definition might be forest owners' use of other funding possibilities available at the national level or simply their slowness to react relative to farmers, who are traditionally more reactive in applying for subsidies. Forest owners are also likely discouraged from applying for grants and subsidies because the funds allocated to forests are disproportionately lower than the funds allocated to farming activities. Ultimately, even if subsidies are available and the forest owners know about them, they still might prefer to not use them at all. Madsen (2003) showed that landowners who receive grants chose not to use them, while landowners who never obtained a grant plant trees anyway. He also showed that when nature orientation is of increasing importance for farmers, planting without subsidies becomes increasingly more likely. This knowledge is important because the economic incentives have been a central instrument in the EU policy. In the context of diverse cultural and societal traits, solutions based on general knowledge may be insufficient. Therefore, incentives based on behavioural particularities are critical when dealing with forest management. The policy on subsidies is currently moving towards a landscape approach instead of sectoral policy approach, which is probably already influencing how advisory services inform and advise forest owners.

\subsection{Differences in the conceptualisation of forest management between Eastern and Western Europe}


Even though all current forest management policies in the seven countries analysed in this study have included the concept of sustainable forest management (Czech Republic in 1995, Slovenia in 1993, Portugal in 1996, United Kingdom in 1998, France in 2001, Slovakia in 2005, Romania in 2008) and the Programme for the Endorsement of Forest Certification (PEFC) has contributed to the adoption of sustainable forest management as a practical framework, there are some differences in the conceptualisation of forest management between Eastern and Western Europe (See Table 6). It is interesting that only in Slovakia and Romania, which were the last countries to have the concept of sustainable forest management officially included in their forest policies, the least agreed definition is not related to an economic-related statement. Table 6 shows that in Slovakia, the least agreed definition is "Imitating natural processes" and in Romania it is "Application of Knowledge". According to Deuffic et al. (in press), even when rules are altered by policy makers to influence individual decisions, forest owners may still refuse to strictly follow the newer policy frames.

Historical reasons might also contribute to the differences. Before the Second World War, Eastern and Western Europe shared strong cultural and institutional ties (Elster et al., 1998). However, the emergence of new political systems in the second part of the $20^{\text {th }}$ century (Angelstam et al., 1997; Lawrence, 2009) and the forest privatisation and restitution process in Eastern Europe in the 1990s changed the ownership structure; consequently, new forest management styles arose (Bouriaud and Schmithüsen, 2005). Nevertheless, though the restitution of forestland to former owners or their heirs re-established private forest ownership, many countries in Eastern Europe continue to use the old forest management planning system, which is compulsory for all private forests. With a few exceptions, forest owners do not participate in the process of setting the management goals in forest planning (Bouriaud et al., 2013; Ficko and Boncina, 2015b). This lack of power, together with lack of income, low salaries or poor previous experience of forest ownership, may explain why the economic aspects of forest management were slightly more important to forest owners in Eastern Europe than to those in Western Europe. Low participation in decision making about the use of forests potentially leads forest owners to blame the state institutions responsible for forest planning for becoming excessively "green" by not prioritising the profitability of forest management (Nichiforel and Schanz, 2011). The ownership structure and the level of participatory decision making were found to also be important predictors of the differences between Eastern and Western conceptualisations of climate change adaptation strategies (Bouriaud et al., 2013).

According to Nijnik et al. (2015), attitudes towards multifunctional forests and the provision of ecosystem services seem to be dependent upon the socioeconomic, political, and historical preconditions, cultural standards, and ethical principles operating in each of the EU countries. In the $19^{\text {th }}$ and $20^{\text {th }}$ centuries, heavy deforestation in Western European countries caused wood shortages and environmental degradation. For example, in Portugal, forest cover was $4-7 \%$ in the 1870 s (Pereira et al., 2009); in France, it was approximately 19\% in 1908 (Koerner et al., 2000; L'iF, 2013). In the United Kingdom, forest cover was only $5 \%$ at the start of the $20^{\text {th }}$ century (Forestry Commission, 2015). This situation triggered a change in strategy from exclusive wood harvesting towards a more integrative approach, which included both the production of commodities and noncommodities (cf. Brown and Harris, 2000; Winkel, 2014). A similar process of dissociating forests from commodity production took place in the Pacific Northwest in the United States in the early 1990s (Winkel, 2014). In the United States, a strong move towards non-intervention and hands-off forest management has been observed among non-industrial private forest owners (e.g., Bengston et al., 2004; Berlik et al. 2002). Therefore, forestry in the West has become a premier tool for delivering "health and well-being benefits for people and a range of other critical ecosystem services including climate change mitigation and adaptation" (Scottish Government, 2016). Rather than being a source that supplies wood and other goods, woodlands and forests have become important for delivering regulation ecosystem services, such as reducing the risks associated with climate change. For instance, to increase its role in addressing the challenge that Scotland faces from climate change, a target has been set to create 100,000 hectares of new woodland between 2012 and 2022 (Scottish 
Government, 2016). In Eastern European countries, forest cover has not been an issue in the past as there were plenty of forest resources. However, if levels of deforestation and illegal logging increase, forest resources might become scarcer and this might trigger Eastern societies to become more aware of the importance of environmental values mirroring what happened previously in the West.

\subsection{Limitations of the study}

As with all studies, this study has some limitations. The data collection design did not allow for random sampling in each country, and different methods for data collection had to be employed in the seven countries, as the availability of forest owners' contact information varied across the seven countries. Snowball sampling and the use of forest owner member lists is subject to selection bias, unclear generalisability and potential systematic sampling errors. In addition, other error sources were associated with the different collection methods used in different countries. Online surveys can induce sample bias errors because social and spatial divides exist in both the access to and the use of the internet. Non-response bias is also an issue, as some social groups (older people) are underrepresented among internet users; different levels of technical ability might be present among the respondents. In face-to-face questionnaires, the quality of the collected data often depended on the interviewer's ability. Telephone interviews invite instant responses and do not encourage fully considered and reflective answers; the responses are more likely to be spontaneous and "off the cuff". The opportunity to include seven countries in the study was prioritised over the consistency of data collection methods and potential sources of errors.

The survey did not include questions that could be useful to explain forest owner's perceptions of forest management in greater detail, for example, type of forest (monoculture, mixed forest), age of the forest, length of ownership, or application for subsidies. This was mostly because the primary interest was to determine the main concepts of forest management and to identify the factors that influence the conceptualisations, but also because the research team considered that a long questionnaire would result in a poor response, especially in the case of face-to-face interviews. Expanding the number of statements and implementing the Q-methodology with fewer respondents would be an alternative approach if the interest was to extract the subjective opinions and the nuances of subjective viewpoints on forest management.

Classification and regression trees have many advantages but also disadvantages in comparison to other regression models. Since CART is a nonparametric and nonlinear technique, it can handle both continuous and discrete data with no implicit assumption about the linear relationships between the predictor variables and the dependent variable; the variables can even be non-monotonic in nature. By combining the automatic methods for building trees with the manual selection of good predictors and splits, CART allows the derivation of the best combination of expert and statistical explanations of the phenomenon without much associated a priori knowledge. However, the major drawbacks of CART are possible overfitting and the resulting poor validity of the model for new data. If not stopped, the tree algorithm ultimately extracts all information from the data, resulting in a perfect model fit. Such a model would probably poorly reproduce unseen data. However, with 10-fold cross validation and proper pruning, the regression tree graphs were validated and remained interpretable. Additionally, the small correlations among the predictors (Table 4) ensured that the decision of the regression tree algorithm to choose the best predictor in a branch did not lead to the exclusion of an equally good predictor. One major drawback of the classification and regression trees is, however, the comprehensibility of the tree, which depends on the tree type, e.g., binary separations (splits) are usually preferred over multiple separations as they are easier to interpret. Different algorithms might provide a completely different result. The regression tree might get too large even after pruning, and separation rules are difficult to interpret, particularly when the input data are complex with many values of the categorical predictors, or when the distribution is highly uneven. The results avoid overreliance on the significance of statistical tests as some of the differences between forest owners in the tree nodes were small considering the rather large sample. 


\section{Conclusion}

This study provides strong empirical evidence that European private forest owners associate forest management with multi-functionality. It challenges the view encountered in most of the scientific literature and the European and national policymakers' rhetoric that private woodland is widely under-managed. The study could help understand the social and psychological barriers the European Union is likely to experience in meeting the wide range of challenges and opportunities outlined in the Rural Development Programmes, as well as the United Kingdom post-Brexit. It can also inform the European Forest Strategy review, which will be carried out in 2018, and will assess the progress of its implementation. The sample of private forest owners in these seven European countries suggests that there is a shared common belief that forest management already occurs through the maintenance of forests for future generations. "Maintenance forest management" challenges the definitions of passive and active forest owners. Another interesting finding is the lower importance given to subsidies compared with other conceptualisations of forest management. This suggests the need for more innovative support schemes and advisory services to encourage forest owners to engage with these schemes. Currently, provisioned co-financing of forestry measures under the Rural Development Regulation implicitly assumes that private forest owners prefer economicscentred forest management (ECON), which is in contrast with the prevailing definition of forest management found in this study. This study also suggests that forest property size, education, age and European region (West, East) determine forest owners' economic expectations in relation to forest management. In Western Europe, forest owners have a more ecosystem-oriented view of forest management than those in Eastern Europe. This can be interpreted as a swing of the forest management paradigm pendulum towards non-commodity objectives but also as a response to political efforts to move away from the exploitation of forest resources to multi-functional management. This raises the following question for future investigation "How does the political history of Europe since World War II, as well as other historical and socio-political background of the countries, influence the psychological dimension of forest ownership?" Clearly, more work needs to be done to understand the social representations of other land-use management and their role and interactions in landscape planning. Inadequate knowledge of stakeholder values may severely undermine the effectiveness of natural resource management strategies (Wallace et al., 2016). Future studies on the role of social representations of forest management as a part of European rural landscapes should use a representative sample of stakeholders and include more countries, preferably using the same measurement instrument and including a spatially explicit modelling of social constructions, which could also be used in rural geography and planning studies.

\section{Acknowledgements}

This paper is written as a part of Cost Action FP1201, Forest Land Ownership Changes in Europe: Significance for Management and Policy (FACESMAP). Laura Bouriaud thanks the Romanian Agency UEFISCDI for helping finance this research through the project PN-II-RU-TE-2014-4-0017. Philippe Deuffic and Elodie Brahic thank Centre National de la Propriete Forestiere (CNPF). The authors are also grateful to the people involved in data collection in the seven European countries. The authors thank the three anonymous reviewers for their useful comments that helped to improve the article.

\section{References}


Abric, J.C., 2001. A structural approach to social representations. In: Deaux, K. and Philogène, G., Editors. Representations of the Social: Bridging Theoretical Traditions. Blackwell Publishing House, Oxford, pp. 42-47.

Agreste, 2013. Structure de la forêt privée en 2012. Des objectifs de production pour un tiers des propriétaires. Agreste Primeur 306, pp. 1-4.

Angelstam, P.K., Anufriev, V.M., Balciauskas, L., Blagovidov, A.K., Borgegård, S.O., Hodge, S.J., Majewski, P., Ponomarenko, S.V., Shvarts, E.A., Tishkov, A.A. and Tomialojc, L., 1997. Biodiversity and sustainable forestry in European forests: how East and west can learn from each other. Wildlife Society Bulletin (1973-2006) 25, pp. 38-48.

Baptista, F. and Santos, R., 2005. Os Proprietários Florestais: Resultados de Um Inquérito. Oeiras, Celta Editora.

Barthod, C., Barrillon, A., Arcangeli, F. and Hermeline, M., 2001. La Loi d'orientation sur la forêt du 9 juillet 2001. Revue Forestière Française 53, pp. 491-510.

Bengston, D.N., Webb, T.J. and Fan, D.P., 2004. Shifting Forest value orientations in the United States, 1980-2001: a computer content analysis. Environmental Values 13, pp. 373-392.

Berlik, M.M., Kittredge, D.B. and Foster, D.R., 2002. The illusion of preservation: a global environmental argument for the local production of natural resources. Journal of Biogeography 29, pp. 1557-1568.

Betts, A. and Ellis, J., 2000. What Woodland Owners Want - an Attitude Survey, A Report Prepared by the Surrey Woodland Working Group. Forestry Commission.

Bouriaud, L. and Schmithüsen, F., 2005. Allocation of property rights on forests through ownership reform and forest policies in central and Eastern European countries. Schweizerische Zeitschrift fur Forstwesen 156, pp. 297-305.

Bouriaud, L., Nichiforel, L., Weiss, G., Bajraktari, A., Curovic, M., Dobrinska, Z., Glavonjic, P., Jarski, V., Sarvasova, Z., Teder, M. and Zalite, Z., 2013. Governance of private forests in eastern and 
Central Europe: an analysis of forest harvesting and management rights. Annals of Forest Research 56, pp. 199-215.

Breiman, L., Friedman, J.H., Olshen, R.A. and Stone, C.I., 1984. Classification and Regression Trees. Belmont, CA, Wadsworth.

Brown, G. and Harris, C.C., 2000. The US Forest Service: whither the new resource management paradigm? Journal of Environmental Management 58, pp. 1-19.

Brukas, V. and Sallnäs, O., 2012. Forest management plan as a policy instrument: carrot, stick or sermon? Land Use Policy 29, pp. 605-613.

Buijs, A., 2009. Lay people's images of nature: comprehensive frameworks of values, beliefs, and value orientations. Society and Natural Resources 22, pp. 417-432.

Burton, J.F., 2004. Seeing Through The 'good farmer's' eyes: towards developing an understanding of the social symbolic value of 'productivist' behaviour. Sociologia Ruralis 44, pp. 195-215.

Cavazza, N. and Rubichi, S., 2014. Ways of thinking about the incinerator: a typology of citizens' mindsets. Social Science Journal 51, pp. 422-430.

Cleaver, F. and de Koning, J., 2012. Institutional bricolage in community forestry: an agenda for future research. In B. Arts, S. Van Bommel, M. Ros-Tonen \& G. Verschoor (eds), ForestPeople Interfaces: Understanding community forestry and biocultural diversity. Wageningen Academic Publishers, Wageningen, The Netherlands.

Church, A. and Ravenscroft, N., 2008. Landowner responses to financial incentive schemes for recreational access to woodlands in south east England. Land Use Policy 25, pp. 1-16.

Davis, M.L.E.S. and Fly, J., 2004. Seeing the landowner through the trees: how non-participant private forest landowners experience their land. A phenomenological investigation. In: Baumgartner, D., Editor. Proceedings of the Conference on Human Dimensions of Family, Farm, and Community Forestry International Symposium, March 29 - April 1, 2004. Washington State University, Pullman, WA, pp. 95-99. 
Davis, M.L.E.S. and Fly, J., 2010. Do you hear what I hear: better understanding how forest management is conceptualized and practised by private forest landowners. Journal of Forestry 108, pp. 321-328.

Dayer, A.A., Broussard Allred, S.B. and Stedman, R.C., 2014. Comparative analysis and assessment of forest landowner typologies. Society \& Natural Resources 27, pp. 1200-1212.

de Koning, J., 2014. Unpredictable Outcomes in Forestry-Governance Institutions in Practice, Society \& Natural Resources, 27 (4), pp. 358-371.

Deuffic, P., Arts, B.J.M. , Sotirov, M. Your policy, my rationale. How individual and structural drivers influence European forest owners' decisions. Land Use Policy, in press.

Dillman, D.A., 2007. Mail and Internet Surveys: The Tailored Design Method, second ed. John Wiley \& Sons, New Jersey.

Doise, W., 1989. Cognitions et représentations sociales: I'approche génétique In: Jodelet, D., Editor. Les représentations sociales, P.U.F., Paris, pp. 341-362.

Elands, B.H.M. and Wiersum, K.F., 2001. Forestry and rural development in Europe: an exploration of socio-political discourses. Forest Policy and Economics 3, pp. 5-16.

Elster, J., Offe, C. and Preuss, U.K., 1998. Institutional Design in Post-Communist Societies: Rebuilding the Ship at Sea. Theories of Institutional Design. Cambridge University Press, Cambridge.

European Commission, 2009. Directive 2009/28/EC of the European Parliament and of the Council of 23 April 2009 on the promotion of the use of energy from renewable sources and amending and subsequently repealing directives 2001/77/EC and 2003/30/EC. Accessible at: http://eur-lex.europa.eu/legal-content/EN/ALL/?uri=CELEX:32009L0028 (accessed 03.08.2016).

European Commission, 2013. A new EU Forest Strategy: for forests and the forest-based sector. Accessible at: http://ec.europa.eu/agriculture/forest/strategy en (accessed 13.02.2107). 
European Commission, 2013. Rural Development in the European Union. Statistical and Economic Information. Report 2013.

European Commission, 2016. Europeans, agriculture and the CAP. Special Eurobarometer 440. Survey requested by the European Commission, Directorate-General for Agriculture and Rural Development and co-ordinated by the Directorate-General for Communication. Accessible at: https://data.europa.eu/euodp/en/data/dataset/S2087_84_2_440_ENG (accessed 03.08.2016).

Ficko, A. and Boncina, A., 2013. Probabilistic typology of management decision making in private forest properties. Forest Policy and Economics 27, pp. 34-43.

Ficko, A. and Boncina, A., 2015a. Forest owner representation of forest management and perception of resource efficiency: a structural equation modelling study. Ecology and Society 20, pp. 36.

Ficko, A. and Boncina, A., 2015b. Forest owner willingness to pay for a forest property plan may reduce public expenditures for forest planning. European Journal of Forest Research 134, pp. 1043-1054.

Follo, G., Lidestav, G., Ludvig, A., Vilkriste, L., Hujala, T., Karppinen, H., Didolot, F. and Mizaraite, D., 2016. Gender in European forest ownership and management: reflections on women as "new forest owners". Scandinavian Journal of Forest Research, pp. 1-36.

Forest Europe, 2011. State of Europe's forests 2011. Status and trends in sustainable forest management in Europe. United Nations Economic Commission for Europe and Food and Agriculture Organization of the United Nations. Accessible at: http://www.unece.org/fileadmin/DAM/publications/timber/Forest_Europe_report_2011_w eb.pdf (accessed 03.08.2016).

Forest Europe, 2015. State of Europe's forests 2015. Food and Agriculture Organization of the United Nations. Accessible at: http://www.foresteurope.org/docs/fullsoef2015.pdf (accessed 03.08.2016). 
Forestry Commission, 2015. Forestry statistics 2015. A compendium of statistics about woodland, forestry and primary wood processing in the United Kingdom. Forestry Commission, Edinburgh. Accessible at: http://www.forestry.gov.uk/pdf/ForestryStatistics2015.pdf/\$FILE/ForestryStatistics2015.pdf (accessed 03.08.2016).

Glynn, M., Anable, J., Quick, T., Richardson, W., Rowcroft, P. and Smith, S., 2012. Independent Panel on Forestry Woodland Owner Survey. Final report to the Independent Panel on Forestry. URS, London. Accessible at:

https://www.gov.uk/government/uploads/system/uploads/attachment_data/file/183095/In dependent-Panel-on-Forestry-Final-Report1.pdf (accessed 03.08.2016).

Gootee, R.S., Blatner, K.A., Baumgartner, D.M., Carroll, M.S. and Weber, E.P., 2010. Choosing what to believe about forests: differences between professional and non-professional evaluative criteria. Small-Scale Forestry 9 (2), pp. 137-152.

Hahn, W.A. and Knoke, T., 2010. Sustainable development and sustainable forestry: analogies, differences, and the role of flexibility. European Journal of Forest Research 129, pp. 787-801. Halfacree, K.H., 1995. Talking about rurality: social representations of the rural as expressed by residents of six English parishes. Journal of Rural Studies 11, pp. 1-20.

Härtl, F. and Knoke, T., 2014. The influence of the oil price on timber supply. Forest Policy and Economics 39, pp. 32-42.

Hill, T. and Lewicki, P., 2007. Statistics: Methods and Applications. StatSoft, Tulsa, OK.

Hodge, I.D. and Adams, W.M., 2013. The future of public forests: an institutional blending approach to forest governance in England. Journal of Rural Studies 31, pp. 23-35.

Hodge, I.D. and Adams, W.M., 2014. Property institutions for rural land conservation: towards a post-neoliberal agenda. Journal of Rural Studies 36, pp. 453-462. 
Hokajärvi, R., Hujala, T., Leskinen, L.A. \& Tikkanen, J., 2009. Effectiveness of sermon policy instruments: forest management planning practices applying the activity theory approach. Silva Fennica 43(5), pp. 889-906.

Hogl, K., Pregernig, M. and Weiss, G., 2005. What is new about new forest owners? A typology of private forest ownership in Austria. Small-scale Forest Economics, Management and Policy 4, pp. 325-342.

Independent Panel on Forestry, 2012. Final report. Department for Environment, Food and Rural Affairs. Accessible at: https://www.gov.uk/government/publications/independent-panel-onforestry-final-report (accessed 13.02.2017).

Ingemarson, F., Lindhagen, A. and Eriksson, L., 2006. A typology of small-scale private forest owners in Sweden. Scandinavian Journal of Forest Research 21, pp. 249-259.

Kanuk, L. and Berenson, C., 1975. Mail surveys and response rates: a literature review. Journal of Marketing Research 12, pp. 44-53.

Karppinen, H., 2012. New Forest owners and owners-to-be: apples and oranges? Small-scale Forestry 11 , pp. 15-26.

Karppinen, H. and Berghäll, S., 2015. Forest owners' stand improvement decisions: applying the theory of planned behavior. Forest Policy and Economics 50, pp. 275-284.

Kindstrand, C., Norman, J., Boman, M. and Mattsson, L., 2008. Attitudes towards various forest functions: a comparison between private forest owners and forest officers. Scandinavian Journal of Forest Resources 23 (2), pp. 133-136.

Kittredge, D.B., 2004. Extension/outreach implications for America's family forest owners. Journal of Forestry 102, pp. 15-18.

Koerner, W., Cinotti, B., Jussy, J.H. and Benoît, M., 2000. Évolution des surfaces boisées en France depuis le début du xixe siècle : identification et localisation des boisements des territoires agricoles abandonnés. Revue Forestière Française 3, pp. 249-269. 
Kvarda, E., 2004. Non-agricultural forest owners in Austria - a new type of forest ownership. Forest Policy and Economics 6, pp. 459-467.

L'iF, 2013. Un siècle d'expansion des forêts françaises. De la statistique Daubrée à l'inventaire forestier de l'IGN. No. 31. I'Institut National De l'information géographique et Forestière (IGN), Saint-Mandé. Acessible at: http://inventaire-forestier.ign.fr/spip/IMG/pdf/IF31.pdf Lawrence, A., 2009. Forestry in transition: imperial legacy and negotiated expertise in Romania and Poland. Forest Policy and Economics 11, pp. 429-436.

Lawrence, A. and Dandy, N., 2014. Private landowners' approaches to planting and managing forests in the UK: what's the evidence? Land Use Policy 36, pp. 351-360.

Leach, J., Hanton, P. and Gurling, H., 2012. Why people buy small woods and what do they do with them? Quarterly Journal of Forestry 106, pp. 19-22.

Lertzman, K., 2009. The paradigm of management, management systems, and resource stewardship. Journal of Ethnobiology 29, pp. 339-358.

Levin, S.A., 2003. Stewardship, concept of. In: Encyclopedia of Biodiversity. Elsevier, New York, pp. 481-494.

Lieskovský, J., Bezák, P., Špulerová, J., Lieskovský, T., Koleda, P., Dobrovodská, M., Bürgi, M. and Gimmi, U., 2015. The abandonment of traditional agricultural landscape in Slovakia - an analysis of extent and driving forces. Journal of Rural Studies 37, pp. 75-84.

Lunnan, A., Nybakk, E. and Vennesland, B., 2006. Entrepreneurial attitudes and probability for startups - an investigation of Norwegian non-industrial private forest owners. Forest Policy and Economics 8, pp. 683-690.

Madsen, L.M., 2003. New woodlands in Denmark: the role of private landowners. Urban Forestry \& Urban Greening 1, pp. 185-195.

Martin, C.L., 1994. The impact of topic interest on mail survey response behavior. Journal of the Market Research Society 36, pp. 327-337. 
Matilainen, A. and Lähdesmäki, M., 2014. Nature-based tourism in private forests: stakeholder management balancing the interests of entrepreneurs and forest owners? Journal of Rural Studies 35, pp. 70-79.

McGuire, J.M., Morton, L.W., Arbuckle, J.G. and Cast, A.D., 2015. Farmer identities and responses to the social-biophysical environment. Journal of Rural Studies 39, pp. 145-155.

Moscovici, S., 2008. Psychoanalysis. Its Image and Its Public. Polity Press, Cambridge, UK.

Ní Dhubháin, Á, Cobanova, R., Karppinen, H., Mizaraite, D., Ritter, E., Slee, B. and Wall, S., 2007. The values and objectives of private forest owners and their influence on forestry behaviour: the implications for entrepreneurship. Small-Scale Forestry 6, pp. 347-357.

Nichiforel, L. and Schanz, H., 2011. Property rights distribution and entrepreneurial rent-seeking in Romanian forestry: a perspective of private forest owners. European Journal of Forest Research 130, pp. 369-381.

Nicholls, D. and Young, M., 2005. Private Woods in Crisis? A Report on a Survey of Private Woodland Estates in England and Wales. University of Cambridge Department of Land Economy and Fitzwilliam College, Cambridge, p. 23.

Nijnik, M., Nijnik, A. and Brown, I. 2015. Exploring the linkages between multifunctional forestry goals and the legacy of spruce plantations in Scotland. Canadian Journal of Forest Research 46, pp. 1-8.

Nybakk, E. and Hansen, E., 2008. Entrepreneurial attitude, innovation and performance among Norwegian nature-based tourism enterprises. Forest Policy and Economics 10, pp. 473-479.

Nybakk, E., Crespell, P., Hansen, E. and Lunnan, A., 2009. Antecedents to forest owner innovativeness: an investigation of the non-timber forest products and services sector. Forest Ecology and Management 257, pp. 608-618.

Pereira, J.S., Correia, A., Correia, A. and Borges, J.G., 2009. Floresta. In: Pereira, H.M., Domingos, T., Vicente, L. and Proença, V., Editors. Ecossistemas e Bem-estar Humano: Avaliação para Portugal do Millenium Ecosystem Assessment. Escolar Editora, Lisboa, pp. 183-211. 
Accessible at:

https://www.researchgate.net/publication/234154361_A_construcao_naval_e_a_destruica o_do_coberto_florestal_em_Portugal_-

_Do_Seculo_XII_ao_Seculo_XX_Ecologia_Lisboa_4_31-42_ISSN_1647-2829 (accessed

03.08.2016).

Quartuch, M.R. and Beckley, T.M., 2014. Carrots and sticks: New Brunswick and Maine forest landowner perceptions toward incentives and regulations. Environmental Management 53, pp. 202-218.

Raes, L., D'Haese, M., Aguirre, N. and Knoke, T., 2016. A portfolio analysis of incentive programmes for conservation, restoration and timber plantations in Southern Ecuador. Land Use Policy 51, pp. $244-259$.

Rametsteiner, E. n.d. A: overall policies, institutions and instruments for sustainable forest management. Pan-European Qualitative Indicators for Sustainable Forest Management: Policies, Institutions and Instruments, pp. 145-165. Accessible at: https://www.unece.org/fileadmin/DAM/publications/timber/Part_A.pdf (accessed 03.08.2016).

Rametsteiner, E. and Kraxner, F., 2003. Europeans and Their Forests. What Do Europeans Think about Forests and Sustainable Forest Management? A Review of Representative Public Opinion Surveys in Europe. FAO and UNECE Forest Communicators Network, Vienna.

Rametsteiner, E., Eichler, L. and Berg, J., 2009. Shaping forest communication in the European Union: public perceptions of forests and forestry. Final report. Accessible at: http://ec.europa.eu/agriculture/fore/publi/public-perception/report_en.pdf (accessed 03.08.2016).

Raymond, C. M., Bieling, C., Fagerholm, N., Martin-Lopez, B. and Plieninger, T., 2015. The farmer as a landscape steward: comparing local understandings of landscape stewardship, landscape values, and land management actions. Ambio 45, pp. 173-184. 
Render, M.G., 2004. The Development of Sub-regional Policy for Sustainable Forestry, with Particular Reference to the Chilterns, UK (Ph.D. dissertation). Buckinghamshire Chilterns University College, Brunel University, UK.

Roessiger, J., Ficko, A., Clasen, C., Griess, V.C. and Knoke, T., 2016. Variability in growth of trees in uneven-aged stands displays the need for optimizing diversified harvest diameters. European Journal of Forest Research 135, pp. 283-295.

Schmithüsen, F. and Hirsch, F., 2010. Private Forest Ownership in Europe. Geneva Timber and Forest Study Paper 26. United Nations, Economic Commission for Europe, Geneva, Switzerland. Accessible at: http://www.unece.org/fileadmin/DAM/timber/publications/SP-26.pdf (accessed 03.08.2016).

Scottish Government, 2016. Getting the best from our land: a land use strategy for Scotland 20162021. Accessible at: http://www.gov.scot/Publications/2016/03/5773 (accessed 03.08.2010).

Serbruyns, I. and Luyssaert, S., 2006. Acceptance of sticks, carrots and sermons as policy instruments for directing private forest management. Forest Policy and Economics 9, pp. 285-296.

Smith, D.P. and Phillips, D.A., 2001. Socio-cultural representations of greentrified Pennine rurality. Journal of Rural Studies 17, pp. 457-469.

Soares da Silva, D., Figueiredo, E., Eusébio, C. and Carneiro, M.J., 2016. The countryside is worth a thousand words - Portuguese representations on rural areas. Journal of Rural Studies 44, pp. 77-88.

Stanislovaitis, A., Brukas, V., Kavaliauskas, M. and Mozgeris, G., 2015. Forest owner is more than her goal: a qualitative typology of Lithuanian owners. Scandinavian Journal of Forest Research 30, pp. $478-491$.

StatSoft Inc., 2014. IBM SPSS Statistics. StatSoft, Tulsa, OK.

Straka, T.J., 2011. Taxonomic review of classical and current literature on the perennial American family forest problem. Forests 2, pp. 660-706. 
Thomas, H.J.D., Paterson, J.S., Metzger, M.J. and Sing, L., 2015. Towards a research agenda for woodland expansion in Scotland. Forest Ecology and Management 349, pp. 149-161. Urquhart, J., Courtney, P. and Slee, B., 2012. Private woodland owners' perspectives on multifunctionality in English woodlands. Journal of Rural Studies 28, pp. 95-106. van der Ploeg, J.D., Franco, J.C. and Borras, S.M., 2015. Land concentration and land grabbing in Europe: a preliminary analysis. Canadian Journal of Development Studies 36, pp. 147-162. van Vliet, J., de Groot, H.L.F., Rietveld, P. and Verburg, P.H., 2015. Manifestations and underlying drivers of agricultural land use change in Europe. Landscape and Urban Planning 133, pp. 24-36.

Wallace, K.J., Wagner, C. and Smith, M.J., 2016. Eliciting human values for conservation planning and decisions: a global issue. Journal of Environmental Management 170, pp. 160-168. doi: 10.1016/j.jenvman.2015.12.036.

Ward, J. and Manley, W., 2002. New Entrants to Land Markets: Final Report. Woodland Policy Group of the GB Wildlife \& Countryside Agencies. The Royal Agricultural College, Cirencester, Gloucestershire GL7 6JS, England.

Wavehill Consulting, 2009. A survey of farmers with woodland on their Land. A report for the Forestry Commission Wales. Wavehill Consulting, Aberaeron, UK. Accessible at: http://www.forestry.gov.uk/newsrele.nsf/webpressreleases/84fdba74afa80d00802576dd00 5946d4 (accessed 03.08.2016).

Weiland, S., 2010. Sustainability transitions in transition countries: forest policy reforms in SouthEastern Europe. Environmental Policy and Governance 20, pp. 397-407.

Wibberley, J., 2002. Sustaining England's woodlands: private woodland owners and the Forestry Commission (FC). Report on four Regional Woodland Consultation Meetings.

Widmann, R.H., Balser, D., Barnett, C., Butler, B.J., Griffith, D.M., Lister, T.W., Moser, W. K., Perry, C.H., Riemann, R. and Woodall, C.W. 2009. Ohio's forests 2006. Resource Bulletin NRS-36. 
U.S. Department of Agriculture, Forest Service, Northern Research Station, Newtown Square, PA.

Winkel, G., 2014. When the pendulum doesn't find its center: environmental narratives, strategies, and forest policy change in the US Pacific Northwest. Global Environmental Change 27, pp. 84-95.

Worrell, R. and Appleby, M.C., 2000. Stewardship of natural resources: definition, ethical and practical aspects. Journal of Agricultural and Environmental Ethics 12, pp. 263-277. 
Table 1: Countries included in the study, data collection methods and sample size

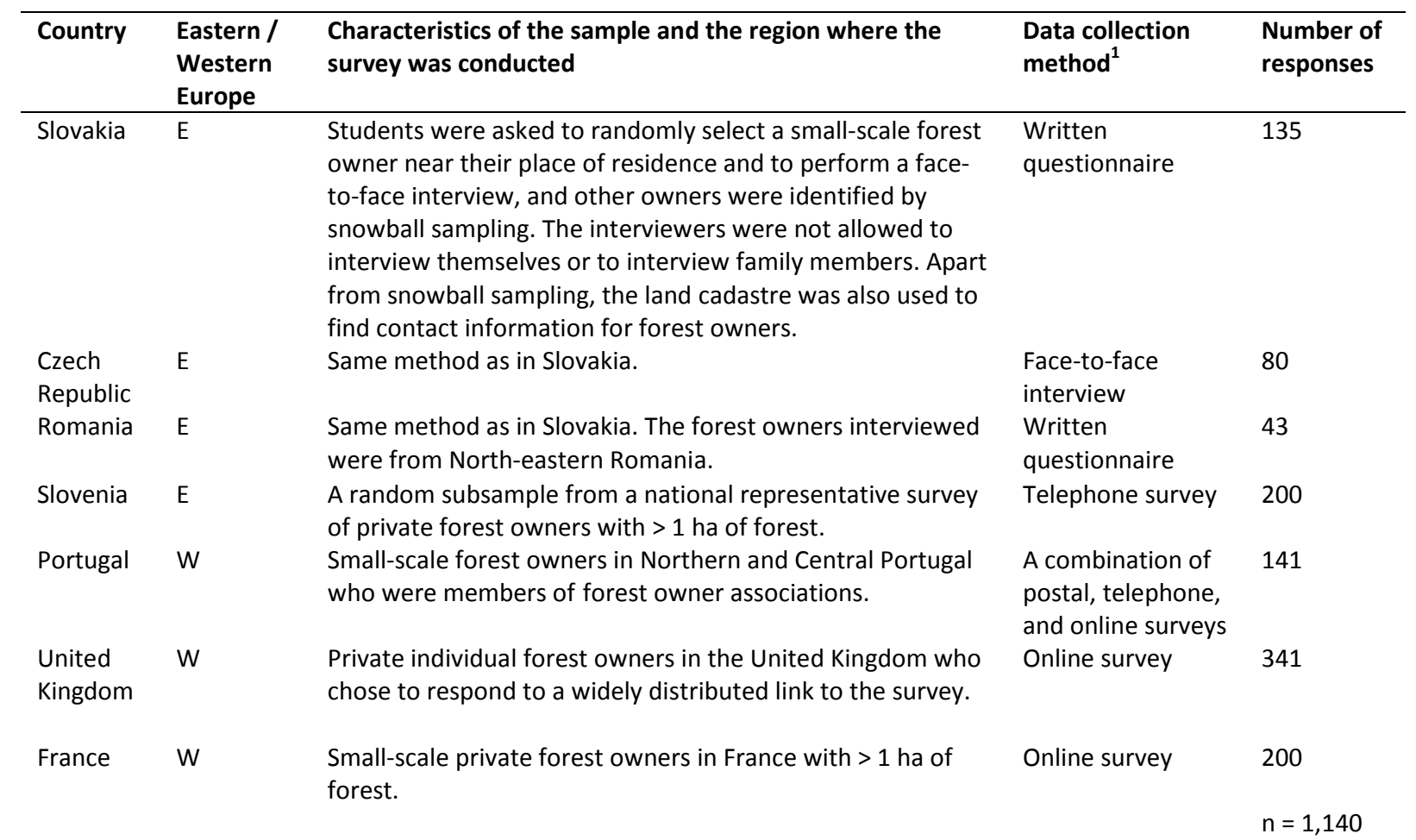

${ }^{1}$ For all countries except Slovenia it was not possible to estimate the non-response bias due to convenience or snowball sampling or the lack of national register of forest owners. For the test of representativeness of the Slovenian data see Ficko and Boncina (2015a).

Table 2: Survey questions adapted from Ficko and Boncina (2015a)

Dependent variable: In your view, forest management is...

1. The application of knowledge to managing the forest

2. The management of capital/the management of an asset

3. Making decisions on what, when and how particular forest stands should be harvested

4. A good business opportunity because it provides good financial revenues

5. Taking care of forest health and maintaining resilience of the forest (e.g. resist the impact of fire, storms)

6. Owning the forest, inspecting the area, taking care of the property and border stones

7. Preserving the forest for the future generations

8. Good opportunity to earn additional money or to improve the family budget

9. Leisure and free-time activity in the woods instead of doing other recreational activities (e.g. hiking, going to the beach)

10. Systematic continuation of the work started by our ancestors

11. Imitating natural processes in the forest (e.g. leaving dead wood, snags, natural regeneration)

12. Undertaking forest operations (e.g. using a chainsaw, winch, other forest operations)

13. Ensuring the regular flow of forest goods for my own consumption (e.g. fuelwood)

14. Ensuring the attractiveness of the neighbourhood environment contributing to the quality of living

15. Preserving large-diameter trees and removing low-quality trees

16. A source of subsidies

17. Keeping the forest beautiful, exactly the way I like it 
18. Ensuring that the forest is not neglected and untidy

19. Cutting large-diameter trees when they are ready to be

cut

Table 3: Descriptive variables per country

\begin{tabular}{|c|c|c|c|c|c|c|c|c|}
\hline Descriptive variables & Statistics & $\begin{array}{l}\text { United } \\
\text { Kingdom }\end{array}$ & Slovenia & Slovakia & $\begin{array}{l}\text { Czech } \\
\text { Republic }\end{array}$ & Portugal & Romania & France \\
\hline \multirow{3}{*}{ Age } & Mean & 58.9 & 62.0 & 43.1 & 46.4 & 54.0 & 50.9 & 57.0 \\
\hline & Min & 21.0 & 33.0 & 22.0 & 20.0 & 19.0 & 22.0 & 24.0 \\
\hline & Max & 75.0 & 85.0 & 77.0 & 79.0 & 81.0 & 78.0 & 85.0 \\
\hline Gender & $\%$ female & 22.0 & 49.0 & 18.5 & 18.8 & 17.7 & 81.4 & 22.0 \\
\hline \multirow{3}{*}{ Total forest area (ha) } & Mean & 70.7 & 5.3 & 448.6 & 85.0 & 17.8 & 21.1 & 9.9 \\
\hline & Min & 0.1 & 0.5 & 0.2 & 0.2 & 0.5 & 0.3 & 1.0 \\
\hline & Max & 9700.0 & 90.3 & 7500.0 & 2000.0 & 200.0 & 279.0 & 250.0 \\
\hline $\begin{array}{l}\text { Education }(1=\text { School, } 2= \\
\text { Diploma/Degree, } 3=\text { Post } \\
\text { graduate, } 4=\text { Vocational }\end{array}$ & Mean & 2.7 & 2.6 & 2.3 & 2.1 & 2.1 & 1.9 & 2.5 \\
\hline
\end{tabular}

Table 4: Spearman's correlations between descriptive variables

\begin{tabular}{|c|c|c|c|c|c|}
\hline & Age & Gender & Size (ha) & Education & West/East \\
\hline Age & & -0.003 & $-0.071^{*}$ & 0.024 & $0.158^{* *}$ \\
\hline Gender & & & $0.168^{* *}$ & 0.033 & $0.179^{* *}$ \\
\hline Size (ha) & & & & -0.011 & 0.030 \\
\hline Education & & & & & $0.105^{* *}$ \\
\hline West/East & & & & & \\
\hline
\end{tabular}

Table 5: Statements defining forest management with means and standard deviations for study items and reliability coefficients for constructs of the pooled sample $(n=1,140)$

\begin{tabular}{|c|c|c|c|c|}
\hline In your view, forest management is... & Mean & S.D. & $\begin{array}{l}\text { Item total } \\
\text { correlation }^{4}\end{array}$ & $\begin{array}{l}\text { Cronbach's alpha } \\
\text { if item deleted }\end{array}$ \\
\hline \multicolumn{5}{|l|}{ Maintenance forest management (MAINT) (Cronbach's alpha $=0.80)$} \\
\hline $\begin{array}{l}\text { q10. The systematic continuation of the work begun by our } \\
\text { ancestors }\end{array}$ & 3.7 & 1.1 & 0.447 & 0.839 \\
\hline $\begin{array}{l}\text { q12. Undertaking forest operations (e.g., using a chainsaw, winch, } \\
\text { or other forest operations) }\end{array}$ & 3.7 & 1.2 & 0.505 & 0.836 \\
\hline $\begin{array}{l}\text { q13. Ensuring the regular flow of forest goods for my own } \\
\text { consumption (e.g., firewood) }\end{array}$ & 3.8 & 1.1 & 0.487 & 0.837 \\
\hline $\begin{array}{l}\text { q14. Ensuring the attractiveness of the neighbouring environment, } \\
\text { thus contributing to quality of life }\end{array}$ & 4.1 & 1.0 & 0.517 & 0.836 \\
\hline $\begin{array}{l}\text { q15. Preserving large-diameter trees and removing low-quality } \\
\text { trees }\end{array}$ & 3.7 & 1.2 & 0.443 & 0.839 \\
\hline q17. Keeping the forest beautiful, exactly the way I like it & 3.8 & 1.2 & 0.508 & 0.836 \\
\hline q18. Ensuring that the forest is not neglected and untidy & 3.9 & 1.1 & 0.488 & 0.837 \\
\hline q19. Cutting large-diameter trees when they are ready to be cut & 3.8 & 1.2 & 0.418 & 0.840 \\
\hline \multicolumn{5}{|l|}{ Ecosystem-centred management $(E M)(C r o n b a c h ' s$ alpha $=0.74)$} \\
\hline q1. The application of knowledge to forest management & 4.2 & 1.0 & 0.392 & 0.841 \\
\hline $\begin{array}{l}\text { q3. Making decisions on what, when and how particular forest } \\
\text { stands should be harvested }\end{array}$ & 3.9 & 1.1 & 0.426 & 0.840 \\
\hline $\begin{array}{l}\text { q5. Taking care of forest health and maintaining the resilience of } \\
\text { the forest (e.g., resisting the impact of fire, storms) }\end{array}$ & 4.2 & 1.0 & 0.524 & 0.837 \\
\hline q6. Owning the forest, inspecting the area, taking care of the & 4.1 & 1.0 & 0.526 & 0.836 \\
\hline
\end{tabular}


property and border stones

q7. Preserving the forest for future generations

q11. Imitating natural processes in the forest (e.g., leaving dead wood, snags, natural regeneration)

Economics-centred management $($ ECON) $($ Cronbach's alpha $=0.70)$

q2. The management of capital/asset

q4. A good business opportunity because it provides good financial revenues

q8. A good opportunity to earn additional money or to improve the family budget

q9. A leisure and free-time activity in the woods instead of other recreational activities (e.g., hiking, going to the beach)

$\begin{array}{llll}4.4 & 1.0 & 0.487 & 0.838 \\ 3.7 & 1.2 & 0.329 & 0.844 \\ & & & \\ 3.5 & 1.3 & 0.375 & 0.843 \\ 2.9 & 1.2 & 0.408 & 0.841 \\ 2.8 & 1.2 & 0.352 & 0.844 \\ 3.4 & 1.3 & \text { Deleted }^{3} & \\ & & & \\ 2.4 & 1.2 & 0.322 & 0.845\end{array}$

$\begin{array}{lllll}\text { q16. A source of subsidies } & 2.4 & 1.2 & 0.322 & 0.845\end{array}$

${ }^{1}$ The forest management concepts confirmed in the study of Ficko and Boncina (2015a) and tested here included maintenance forest management (MAINT), ecosystem-centred management (EM) and economics-centred management (ECON).

${ }^{2}$ Kaiser-Meyer-Olkin measure of sampling adequacy $=0.856, p>0.01$, and Bartlett's test of sphericity $=6212.062, p<$ 0.0001 , indicate that the data were suitable for structure detection.

${ }^{3}$ The statement $q 9$ was removed from the ECON scale to increase its reliability, as suggested by the Cronbach's alpha test (the exclusion of q9 increased the reliability from 0.67 to 0.70 ).

${ }^{4}$ The corrected item-total correlation; correlation (Pearson) coefficient between the score on the individual item and the sum of the scores on the remaining items.

Table 6: Most and least agreed upon statements per categories of control variables

\begin{tabular}{|c|c|c|c|c|c|}
\hline $\begin{array}{l}\text { Control } \\
\text { variable }\end{array}$ & $\begin{array}{l}\text { Category (number of } \\
\text { observations }{ }^{1} \text { ) }\end{array}$ & $\begin{array}{l}\text { Most agreed-upon } \\
\text { definition }\end{array}$ & $\begin{array}{l}\text { Mean } \\
\text { (S.D.) }\end{array}$ & $\begin{array}{l}\text { Least agreed-upon } \\
\text { definition }\end{array}$ & $\begin{array}{l}\text { Mean } \\
\text { (S.D.) }\end{array}$ \\
\hline \multirow[b]{2}{*}{ Gender } & Female (317) & $\begin{array}{l}\text { Preserving for future } \\
\text { generations }\end{array}$ & $\begin{array}{l}4.24^{*} \\
(1.07)\end{array}$ & $\begin{array}{l}\text { Earn additional money and } \\
\text { improve family budget }\end{array}$ & $\begin{array}{l}2.86 \\
(1.29)\end{array}$ \\
\hline & Male (801) & $\begin{array}{l}\text { Preserving for future } \\
\text { generations }\end{array}$ & $\begin{array}{l}4.46^{*} \\
(0.89)\end{array}$ & $\begin{array}{l}\text { Good business opportunity } \\
\text { because it provides good } \\
\text { financial revenues }\end{array}$ & $\begin{array}{l}2.90 \\
(1.21)\end{array}$ \\
\hline \multirow{5}{*}{ Education } & School (224) & $\begin{array}{l}\text { Preserving for future } \\
\text { generations }\end{array}$ & $\begin{array}{l}4.29 * \\
(1.06)\end{array}$ & $\begin{array}{l}\text { Earn additional money and } \\
\text { improve family budget }\end{array}$ & $\begin{array}{l}2.88 \\
(1.23)\end{array}$ \\
\hline & Diploma or degree (307) & $\begin{array}{l}\text { Preserving for future } \\
\text { generations }\end{array}$ & $\begin{array}{l}4.35 \\
(1.01)\end{array}$ & $\begin{array}{l}\text { Good business opportunity } \\
\text { because it provides good } \\
\text { financial revenues }\end{array}$ & $\begin{array}{l}3.17 \\
(1.26)\end{array}$ \\
\hline & Post-graduate degree (387) & $\begin{array}{l}\text { Preserving for future } \\
\text { generations }\end{array}$ & $\begin{array}{l}4.44 \\
(0.87)\end{array}$ & $\begin{array}{l}\text { Good business opportunity } \\
\text { because it provides good } \\
\text { financial revenues }\end{array}$ & $\begin{array}{l}2.74 \\
(1.26)\end{array}$ \\
\hline & $\begin{array}{l}\text { Vocational qualification } \\
\text { (167) }\end{array}$ & $\begin{array}{l}\text { Preserving for future } \\
\text { generations }\end{array}$ & $\begin{array}{l}4.56^{*} \\
(0.80)\end{array}$ & $\begin{array}{l}\text { Good business opportunity } \\
\text { because it provides good } \\
\text { financial revenues }\end{array}$ & $\begin{array}{l}2.79 \\
(1.24)\end{array}$ \\
\hline & United Kingdom (341) & $\begin{array}{l}\text { Preserving for future } \\
\text { generations }\end{array}$ & $\begin{array}{l}4.63 \\
(0.76)\end{array}$ & $\begin{array}{l}\text { Earn additional money and } \\
\text { improve family budget }\end{array}$ & $\begin{array}{l}2.50 \\
(1.17)\end{array}$ \\
\hline \multirow{5}{*}{ Country } & Slovenia (200) & $\begin{array}{l}\text { Preserving large-diameter } \\
\text { trees }\end{array}$ & $\begin{array}{l}4.30 \\
(1.15)\end{array}$ & $\begin{array}{l}\text { Good business opportunity } \\
\text { because it provides good } \\
\text { financial revenues }\end{array}$ & $\begin{array}{l}2.74 \\
(1.12)\end{array}$ \\
\hline & Slovakia (135) & $\begin{array}{l}\text { Preserving for future } \\
\text { generations }\end{array}$ & $\begin{array}{l}4.64 \\
(0.85)\end{array}$ & Imitating natural processes & $\begin{array}{l}2.89 \\
(1.07)\end{array}$ \\
\hline & Czech Republic (80) & $\begin{array}{l}\text { Preserving for future } \\
\text { generations }\end{array}$ & $\begin{array}{l}4.31 \\
(1.13)\end{array}$ & A source of subsidies & $\begin{array}{l}3.06 \\
(1.24)\end{array}$ \\
\hline & Portugal (141) & $\begin{array}{l}\text { Preserving for future } \\
\text { generations }\end{array}$ & $\begin{array}{l}4.63 \\
(0.83)\end{array}$ & Management of capital & $\begin{array}{l}3.48 \\
(1.31)\end{array}$ \\
\hline & Romania (43) & $\begin{array}{l}\text { Ensuring forest goods for } \\
\text { own consumption }\end{array}$ & $\begin{array}{l}4.43 \\
(0.99)\end{array}$ & Application of knowledge & $\begin{array}{l}3.33 \\
(1.44)\end{array}$ \\
\hline \multirow{3}{*}{ East/West } & France (200) & $\begin{array}{l}\text { Preserving the forest for } \\
\text { the future generations }\end{array}$ & $\begin{array}{l}4.29 \\
(0.92)\end{array}$ & A source of subsidies & $\begin{array}{l}2.21 \\
(1.03)\end{array}$ \\
\hline & Eastern European countries & $\begin{array}{l}\text { Preserving the forest for } \\
\text { the future generations }\end{array}$ & $\begin{array}{l}4.27^{*} \\
(1.01)\end{array}$ & A source of subsidies & $\begin{array}{l}2.63 \\
(1.35)\end{array}$ \\
\hline & Western European & Preserving the forest for & $4.49 *$ & A source of subsidies & 2.32 \\
\hline
\end{tabular}


${ }^{1}$ The number of observations in each category adds up to a different total because of the item non-responses.

*Indicates a significant difference at the $p=0.05$ value in the mean values of the categories calculated by the independent sample t-test.

Table 7: Internal reliability of the scales measuring the three forest management concepts and the differences in Eastern and Western European forest owners' agreement with the concepts ( $n=$ $1,140)$

\begin{tabular}{|c|c|c|c|c|c|c|}
\hline \multirow{3}{*}{ Forest management concept } & \multicolumn{6}{|c|}{ Europe } \\
\hline & \multicolumn{2}{|c|}{$\begin{array}{l}\text { Eastern }(n= \\
458)\end{array}$} & \multicolumn{2}{|c|}{$\begin{array}{l}\text { Western }(n= \\
682)\end{array}$} & \multicolumn{2}{|c|}{ All $(n=1,140)$} \\
\hline & Mean & S.D. & Mean & S.D. & Mean & S.D. \\
\hline Maintenance forest management (MAINT) & 3.9 & 0.8 & 3.7 & 0.7 & 3.8 & 0.7 \\
\hline Ecosystem-centred management (EM) & 3.9 & 0.8 & 4.2 & 0.6 & 4.1 & 0.7 \\
\hline Economics-centred management (ECON) & 3.0 & 0.9 & 2.9 & 0.9 & 2.9 & 0.9 \\
\hline
\end{tabular}

Table 8: Summary of the main characteristics for individuals with higher and lower scores for the three concepts of forest management (MAINT, EM and ECON)

\section{MAINT (Maintenance forest management)}

\begin{tabular}{|l|l|}
$\begin{array}{l}\text { High } \\
\text { Eastern Europe }\end{array}$ & Low \\
Small properties & Western Europe \\
Locational qualification & $\begin{array}{l}\text { Large properties } \\
\text { Low levels of education } \\
\text { Middle-aged owners }\end{array}$ \\
\hline EM (Ecosystem-centred management) & Low owners \\
\hline High & Eastern Europe \\
Western Europe & Large properties \\
Medium-sized properties & Elderly owners \\
Young owners & \\
\hline ECON (Economics-centred management) & Low \\
High & Small properties \\
Medium-sized properties & Elderly owners \\
Low level of education & \\
Middle-aged owners &
\end{tabular}




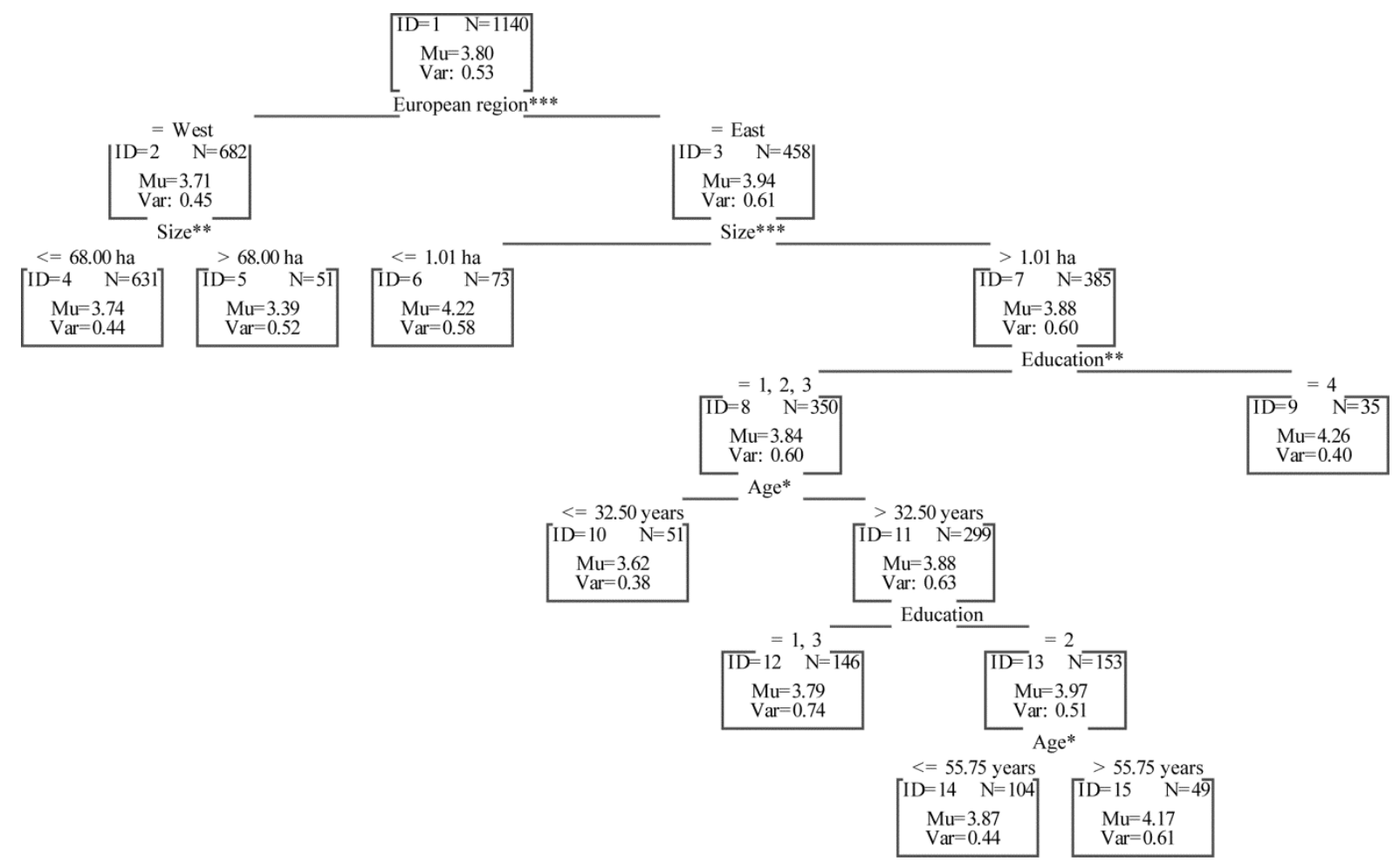

Figure 1: Factors influencing the adoption of the maintenance forest management (MAINT) among European forest owners $(n=1,140)$. The regression tree graph provides information about the node size $(\mathrm{N})$, the mean $(\mathrm{Mu})$ and variance (Var) of the node and the statistical significance of the difference in the branch. Asterisks ***,** and * indicate significant differences at $p<0.001,0.01$ and 0.05 , respectively. The importance of predictors can also be determined from the regression tree, i.e., the highest predictor in the hierarchy is the most important. Education categories: School (1), Diploma or degree (2), Post-graduate degree (3), and Vocational qualification (4). 


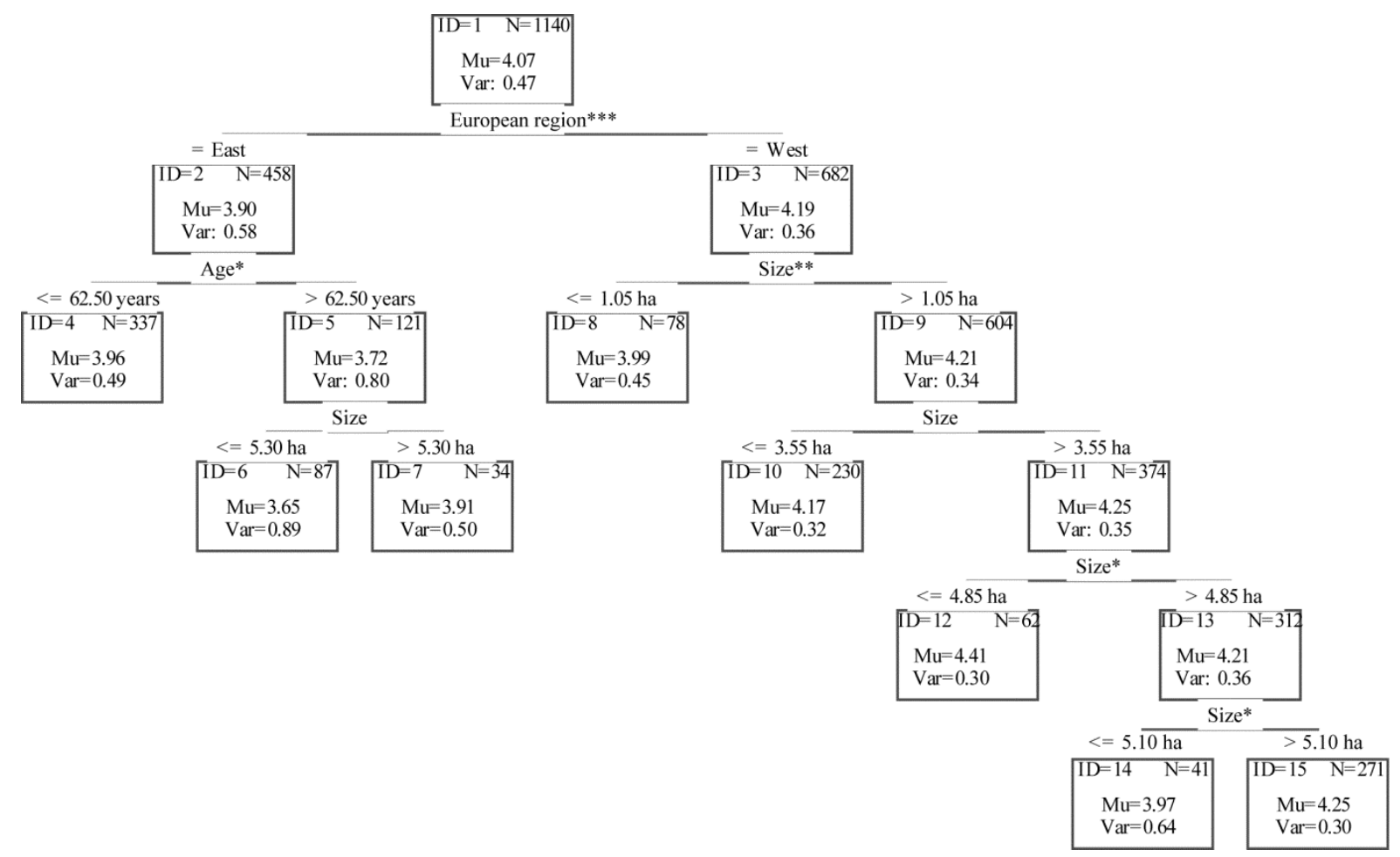

Figure 2: Factors influencing the preference for ecosystem-centred forest management (EM) among European forest owners $(n=1,140)$. The regression tree graph provides information about the node size $(\mathrm{N})$, the mean $(\mathrm{Mu})$ and variance (Var) of the node and the statistical significance of the difference in the branch. Asterisks ***,** and * indicate significant differences at $p<0.001,0.01$ and 0.05 , respectively. The importance of predictors can also be determined from the regression tree, i.e., the highest predictor in the hierarchy is the most important. Education categories: School (1), Diploma or degree (2), Post-graduate degree (3), and Vocational qualification (4). 


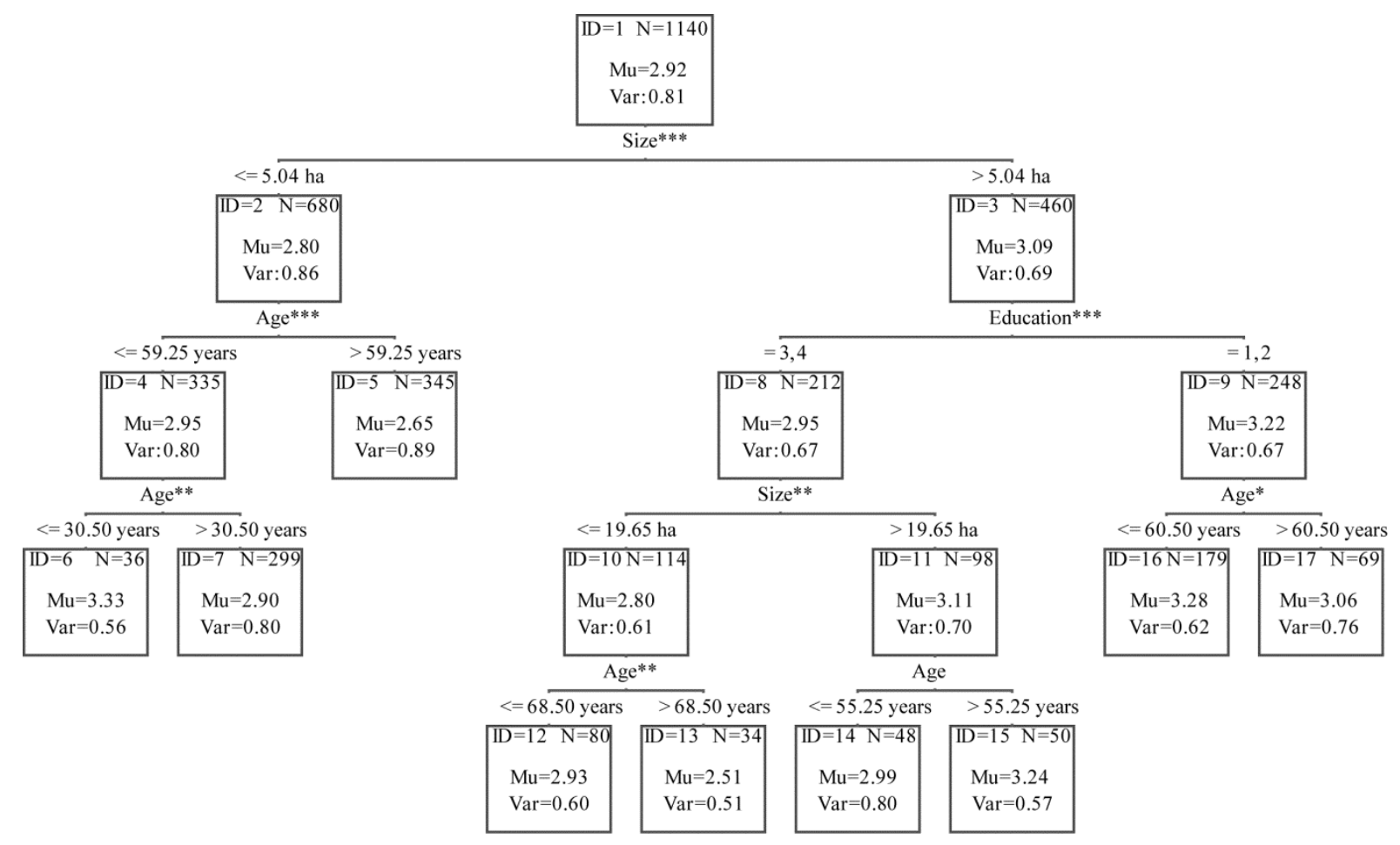

Figure 3: Factors influencing the preference for the economics-centred forest management (ECON) among European forest owners $(n=1,140)$. The regression tree graph provides information about the node size $(\mathrm{N})$, the mean $(\mathrm{Mu})$ and variance $(\mathrm{Var})$ of the node and the statistical significance of the difference in the branch. Asterisks $* * *, * *$ and $*$ indicate significant differences at $\mathrm{p}<0.001,0.01$ and 0.05 , respectively. The importance of predictors can also be determined from the regression tree, i.e., the highest predictor in the hierarchy is the most important. Education categories: School (1), Diploma or degree (2), Post-graduate degree (3), and Vocational qualification (4). 